\title{
Tillering and Structural Characteristics of Panicum Cultivars in the Brazilian Semiarid Region
}

\author{
Emmanuel Lievio de Lima Veras ${ }^{1}{ }^{1}$, , Gelson dos Santos Difante ${ }^{1}(\mathbb{D}$, \\ Antonio Leandro Chaves Gurgel ${ }^{1, *} \mathbb{C}^{-}$, Ana Beatriz Graciano da Costa ${ }^{1}(\mathbb{D}$, \\ Jéssica Gomes Rodrigues ${ }^{1}{ }^{(0}$, Carolina Marques Costa ${ }^{1}{ }^{\circledR}$, João Virginio Emerenciano Neto ${ }^{2}(\mathbb{D}$, \\ Marislayne de Gusmão Pereira ${ }^{1}\left[\right.$ and Pablo Ramon Costa ${ }^{3}$ \\ 1 Faculty of Veterinary Medicine and Animal Science, Federal University of Mato Grosso do Sul, \\ Campo Grande 79070-900, Mato Grosso do Sul, Brazil; emmanuel.veras@hotmail.com (E.L.d.L.V.); \\ gdifante@hotmail.com (G.d.S.D.); beatrizcosta.0303@hotmail.com (A.B.G.d.C.); \\ jessicagr1993@outlook.com (J.G.R.); carolinaufgd@hotmail.com (C.M.C.); \\ marislayne@outlook.com (M.d.G.P.) \\ 2 Campus of Agricultural Sciences, Federal University of Vale do São Francisco, Petrolina 56304-917, \\ Pernabuco, Brazil; joao_neto@zootecnista.com.br \\ 3 Academic Unit Specializing in Agricultural Science, Federal University of Rio Grande do Norte, \\ Macaíba 59280-000, Rio Grande do Norte, Brazil; ramonpablo197@gmail.com \\ * Correspondence: antonioleandro09@gmail.com; Tel.: +55-81-99944-9752
}

Received: 11 March 2020; Accepted: 25 March 2020; Published: 8 May 2020

\begin{abstract}
Panicum maximum grasses are among the most used in Brazil because they have high forage production potential, nutritional value and adaptation to different climate conditions and in poor soils, which have been improved by the application of dolomitic limestone and nitrogen fertilizers and $\mathrm{K}_{2} \mathrm{O}, \mathrm{P}_{2} \mathrm{O}_{5}$. The aim was to evaluate the tillering capacity and structural characteristics of six cultivars of Panicum maximum in the Brazilian semiarid region. The test was configured as a randomized block design with six treatments—-the cultivars Aruana, Massai, Mombaça, Tamani, Tanzânia, and Zuri-and four replications. The studied variables included tiller population dynamics, tiller population density (TPD), appearance rate (ApR), mortality (MorB), tiller survival (SuvP), tiller stability index, height, light interception (LI), forage mass (FM), and morphological constituents. As to the population dynamics of tillers, seven generations were evaluated, and the largest number of tillers was observed in the first generation, regardless of the cultivar. Furthermore, the Massai cultivar demonstrated the highest TPD in all generations. Interaction between the cultivar and evaluation period was noted for ApR: the cultivars Tamani and Tanzânia indicated higher ApR at 122 and 137 days after establishment. The cultivar $(\mathrm{P}=0.380)$ and evaluation period $(\mathrm{P}=0.4469)$ had no effect on SuvP; however, higher MorB was detected in the cultivars Aruana and Tamani compared to Mombaça and Zuri, with intermediate values detected in the other cultivars. The highest FM was observed in the cultivars Massai, Mombaça, and Tamani, as well as in the leaf blade of Massai and Mombaça. The cultivars Massai, Mombaça, Tamani, Tanzânia, and Zuri have the potential to be cultivated in areas with marked water deficit and high temperatures, such as the Brazilian semiarid region. The cultivar Massai has a rapid recovery after a period of water scarcity. The cultivar Aruana is not recommended for use in the Brazilian semiarid region under rainfed conditions.
\end{abstract}

Keywords: tiller number; forage mass; grass; pasture

\section{Introduction}

The sustainability of production systems depends on the development of techniques that allow increasing production without necessarily resulting in an increase in the area used for pasture. 
The grasses of the species Panicum maximum stand out among the other forage grasses used in Brazil because they have high forage production potential, nutritional value, and adaptation to different soil and climate conditions [1-3]. Nevertheless, the potential for Panicum cultivars to adapt despite water scarcity and lengthy droughts, which occur in the Brazilian semiarid region, remains unknown.

Plant responses to the combined effects of drought and elevated temperatures are more complicated to study than those to the distinct effects of isolated environmental factors [4]. Water shortage and high temperatures are the variables that most limit plant productivity, in addition to reducing forage quality and production [5].

Understanding the population dynamics of tillers through parameters such as density, appearance, mortality, survival, and the stability of the tiller population is essential to define management practices that should guarantee the longevity, productivity, and sustainability of pastures throughout the year [6]. As tillering is greatly influenced by water balance, water retention capacity, soil fertility, canopy light interception, solar radiation, and ambient temperature [6-9], production in the dry season can limit regrowth capacity and consequently forage production [10]. The correct choice of cultivars adapted with persistence and the ability to produce new tissues in the Brazilian semiarid region's edaphoclimatic conditions are necessary to optimize forage production in this region, which faces great irregularity in rainfall distribution and high rates of evapotranspiration [11].

The cultivars of Panicum maximum were presumed to have tillering capacity, survival, and forage production, with the potential to be used in regions of semiarid climate in Brazil. The aim was thus to evaluate the tillering dynamics and structural characteristics of six cultivars of Panicum in the Brazilian semiarid region.

\section{Materials and Methods}

\subsection{Site}

The research was conducted in the experimental area of the Forragiculture Study Group at the Federal University of Rio Grande do Norte (UFRN) in Macaíba, Rio Grande do Norte, Brazil ( $5^{\circ} 53^{\prime} 35.12^{\prime \prime} \mathrm{S}, 35^{\circ} 21^{\prime} 47.03^{\prime \prime} \mathrm{W}, 11 \mathrm{~m}$ above sea level), from September 2016 to April 2017. The region's climate is hot and dry, Bsh'W according to the Köppen classification, with a water surplus in May and August [12].

A rain gauge installed at the experiment site was used to measure the climatic data. Data on temperatures and evapotranspiration were obtained from the platform of the National Institute of Meteorology, while the soil water balance (Figure 1) was calculated by adopting a soil water retention capacity of $25 \mathrm{~mm}$.

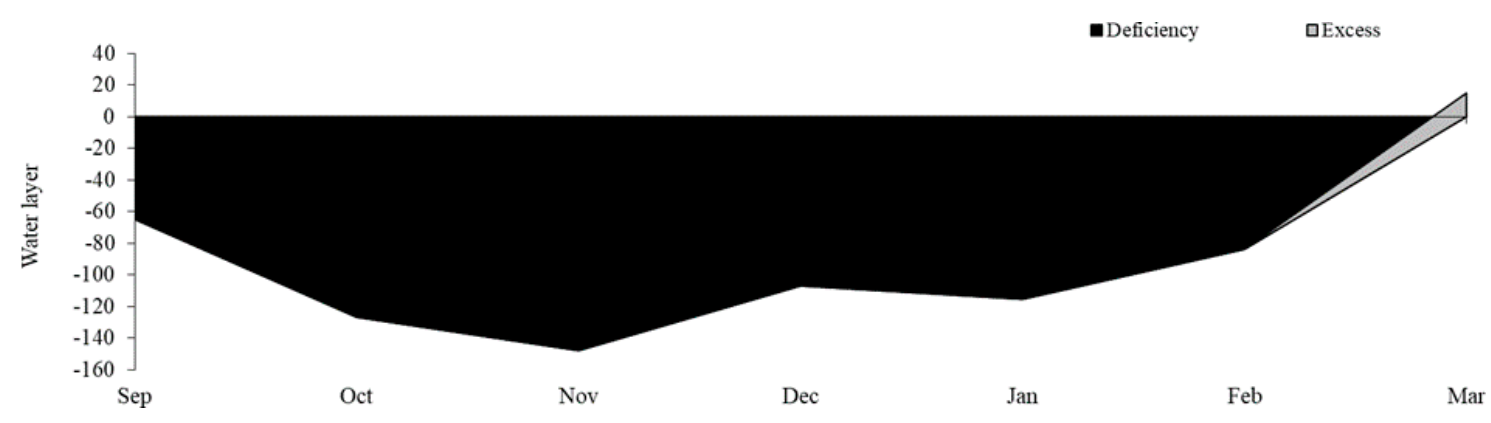

Figure 1. Soil water balance during the experimental period at water retention capacity of $25 \mathrm{~mm}$.

The soil in the area, classified as Arenosol, has sand or soft sand texture in all horizons up to a minimum depth of $150 \mathrm{~cm}$ and practically no alterable primary minerals [13]. At the beginning of the experiment, chemical analyses of the soil were performed at depths of $0-20 \mathrm{~cm}$ and $20-40 \mathrm{~cm}$ (Table 1). Based on these results, $500 \mathrm{~kg} \mathrm{ha}^{-1} \mathrm{CaO}, 105 \mathrm{~kg} \mathrm{ha}^{-1}$ of $\mathrm{P}_{2} \mathrm{O}_{5}$, and $164 \mathrm{~kg} \mathrm{ha}^{-1}$ of $\mathrm{K}_{2} 0$ were applied; 
the nitrogen fertilization of ammonium sulfate was also applied, in installments, 42 days after sowing $\left(50 \mathrm{~kg} \mathrm{ha}^{-1}\right.$ of $\left.\mathrm{N}\right)$ and after the uniform cut $\left(50 \mathrm{~kg} \mathrm{ha}^{-1}\right.$ of $\left.\mathrm{N}\right)$.

Table 1. Chemical characteristics of the soil in the experimental area at the depths of $0-20 \mathrm{~cm}$ and $20-40 \mathrm{~cm}$.

\begin{tabular}{|c|c|c|c|c|c|c|c|c|c|c|c|c|c|}
\hline \multirow{2}{*}{$\begin{array}{l}\text { Layer } \\
(\mathrm{cm})\end{array}$} & $\mathbf{P}$ & $\mathbf{K}$ & $\mathbf{N a}$ & \multirow{2}{*}{$\mathrm{pH} \mathrm{H}_{2} \mathrm{O}$} & $\mathrm{Ca}$ & $\mathrm{Mg}$ & Al & $\mathrm{H}+\mathrm{Al}$ & CEC & \multirow{2}{*}{ BS (\%) } & \multicolumn{3}{|c|}{ Particle Size (\%) } \\
\hline & \multicolumn{3}{|c|}{$\mathrm{mg} \mathrm{dm}^{-3}$} & & \multicolumn{5}{|c|}{$\mathrm{cmol}_{\mathrm{c}} \mathrm{dm}^{-3}$} & & Sand & Silt & Clay \\
\hline $0-20$ & 18 & 63 & 20 & 6.6 & 3.1 & 0.2 & - & 1.2 & 4.4 & 72.7 & 84.6 & 4 & 11.4 \\
\hline $20-40$ & 8 & 49 & 13 & 5.6 & 0.9 & 0.1 & - & 1.1 & 2.2 & 50 & 85.2 & 2 & 12.8 \\
\hline
\end{tabular}

CEC: cation exchange capacity; BS: base saturation.

\subsection{Experiment}

The test was designed in random blocks, with six treatments and four replications. The treatments included six cultivars of Panicum maximum: Aruana, Massai, Mombaça, Tamani, Tanzânia, and Zuri.

The experimental area was $750 \mathrm{~m}^{2}$, with 24 plots divided into four blocks. Each block was composed of six plots, with a spacing of $1 \mathrm{~m}$ between plots and $2 \mathrm{~m}$ between blocks. The plots measured $4 \mathrm{~m}^{2}$, containing $1.3 \mathrm{~m}^{2}$ of floor area, and $0.70 \mathrm{~m}^{2}$ on each side were considered border areas. The cultivars were implanted in April 2016. Between 50 and 70 pure seeds were used per $\mathrm{m}^{2}$. The sowing was executed manually after the soil preparation, and the sowing depth was $1-3 \mathrm{~cm}$. A manual roller was used to improve the soil-seed contact. The uniform cut was made $15 \mathrm{~cm}$ above ground level, 110 days after sowing.

\subsection{Assessments}

\subsubsection{Tiller Population Dynamics}

Three clumps were marked in each experimental unit to evaluate the population dynamics of tillers. In the first evaluation, all the tillers of each clump were marked with threads of a single color and considered the first generation of tillers. For each subsequent evaluation, the tiller marking and counting process was repeated, with the new tillers marked with threads of a new color to identify the new generations of tillers that emerged. With each generation, the live and dead tillers were differentiated and accounted for.

From these data, the following variables were calculated: tiller appearance rate (ApR)-the number of new tillers (last marked generation)/the number of existing tillers (previously marked generation) $* 100$; tiller mortality rate (MorB) — the number of previously marked tillers—the number of surviving tillers (current count)/the number of tillers in the previous dial ${ }^{*} 100$; and tiller survival rate (SuvP)—-the probability of tillers to survive during the 28-day period. The stability index (P1/P0) of the tiller population was determined using the following equation: $\mathrm{P} 1 / \mathrm{P} 0=\mathrm{SuvP}(1+\mathrm{ApR})$, where SuvP $=1-$ MorB. All variables were calculated according to Bahmani et al. [14].

\subsubsection{Pasture Height}

Canopy height was measured by using a centimeter-graduated ruler at three random points per plot before each harvest. The height of each point corresponded to the height of the average curvature of the leaves in the canopy around the ruler.

\subsubsection{Canopy Light Interception}

Light interception (LI) was estimated before each harvest by using a canopy analyzer (AccuPAR Linear PAR/LAI ceptometer, Model PAR-80, DECAGON Devices ${ }^{\circledR}$ ). For each evaluation, eight readings were conducted above the canopy and three at soil level in each experimental plot between 10 and $12 \mathrm{~h}$. The following formula was used for the calculation: \% LI $=100 \%$-(soil level/above soil ${ }^{*} 100$ ). 


\subsubsection{Tiller Population Density}

Tiller population density (TPD; tiller $/ \mathrm{m}^{2}$ ) was obtained by counting the number of tillers in a defined area of $0.09 \mathrm{~m}^{2}$ per plot every 28 days. The choice of sampling points considered the average condition of the plot after the uniform cut. The areas remained fixed during the experimental period.

\subsubsection{Forage Mass and Morphological Constituents}

Forage mass (FM) was estimated by cutting and weighing the forage. For this purpose, a $1 \mathrm{~m}^{2}$ square was used, serving as a basis for all the forage inside to be cut at a height of $15 \mathrm{~cm}$ from ground level. It was then separated into two sub-samples. The first sub-sample was weighed to determine the green weight and dried in the forced air circulation oven at $55^{\circ} \mathrm{C}$ for $72 \mathrm{~h}$ to determine the dry mass.

The second sub-sample was used to separate the morphological constituents in the following fractions: leaf blade, stem (stem and sheath), and dead material. These components were also dried in an oven. With information on the dry weight of each fraction of the sample, the dry mass was estimated, and the calculations of the percentages of leaf blade, stem, and dead material fractions, as well as the leaf/stem ratio, were calculated. The values of FM and morphological constituents were converted to $\mathrm{kg} \mathrm{ha}^{-1}$ dry matter.

\subsection{Statistical Analysis}

Analyses were performed using R software version 3.5.0 (R Development Core Team, 2016). Data concerning the TAR, TMR, and TSR variables were subjected to analysis of variance according to the following statistical model:

$$
Y i j k=\mu+B i+M j+\alpha i j+C k+(M C) j k+\beta i j k
$$

where Yijk is the observed value in block $i$, cultivar $j$, and evaluation period $k ; \mu$ is the overall mean effect; $B i$ is the effect of block $i$; $M j$ is the effect of cultivar $j(j$ is Aruana, Massai, Mombaça, Tamani, Tanzânia, or Zuri); $\alpha \mathrm{ij}$ is the effect of the random error attributed to the plot; $\mathrm{Ck}$ is the effect of the evaluation sampling period $\mathrm{k}(\mathrm{k}=1-6) ;(\mathrm{MC}) \mathrm{j} \mathrm{k}$ is the interaction effect between cultivar $\mathrm{j}$ and sampling period $\mathrm{k}$; and $\beta \mathrm{ijk}$ is the effect of the random error attributed to the subplot.

In the analysis of pasture structural variables, only the cultivar was considered a fixed effect. When found significant by the F test, the effects of sources of variation and their interactions were confirmed by Tukey's test at the 5\% significance level.

\section{Results}

\subsection{Tiller Population Dynamics}

The population dynamics of tillers were assessed through seven generations (Figure 2). The largest number of tillers was observed in the first generation, regardless of the cultivar. The cultivar Massai had the largest tiller population in all generations; conversely, the cultivars Aruana and Zuri have always had generations with lower tiller numbers. The lowest tiller appearance was observed in the third and fourth generations, regardless of the cultivar evaluated. The appearance of tillers increased after the fourth generation and was more expressive in the cultivar Massai in the seventh generation, although it was less intense than in the first and second generations. 
Massai

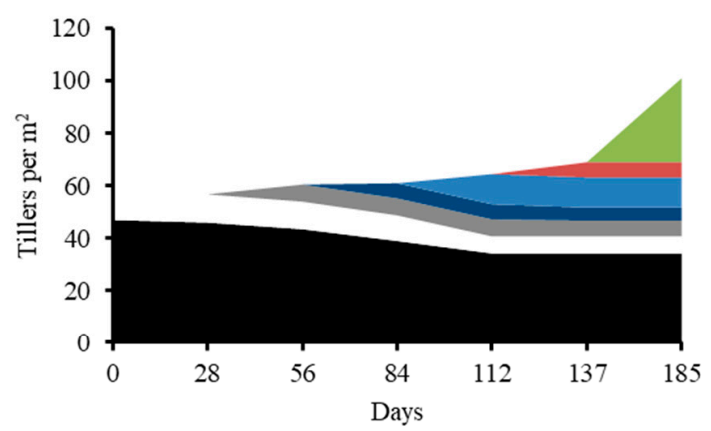

Aruana

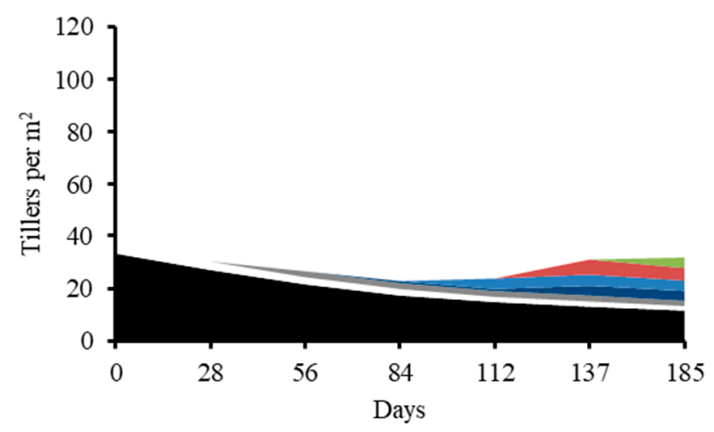

Mombaça

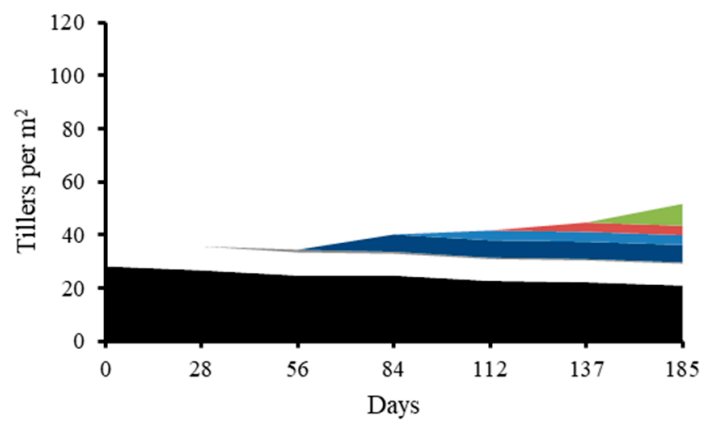

Tanzânia

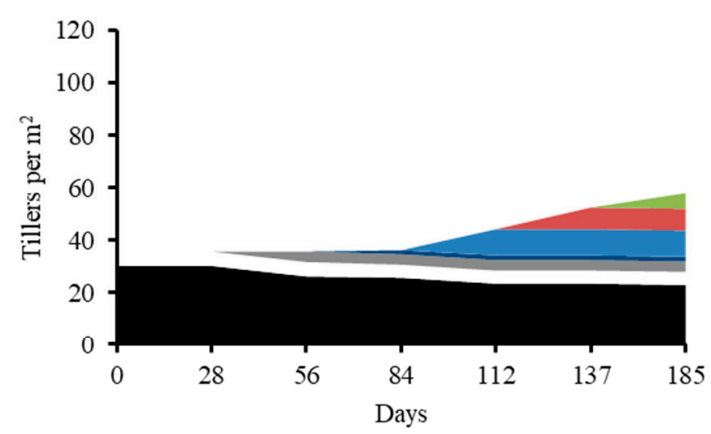

Zuri

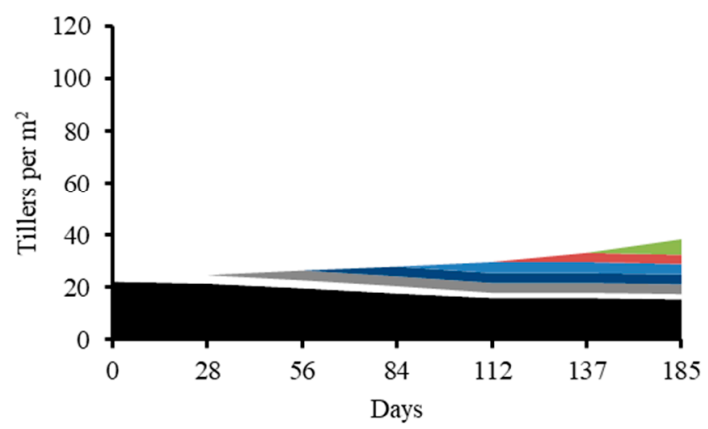

Tamani

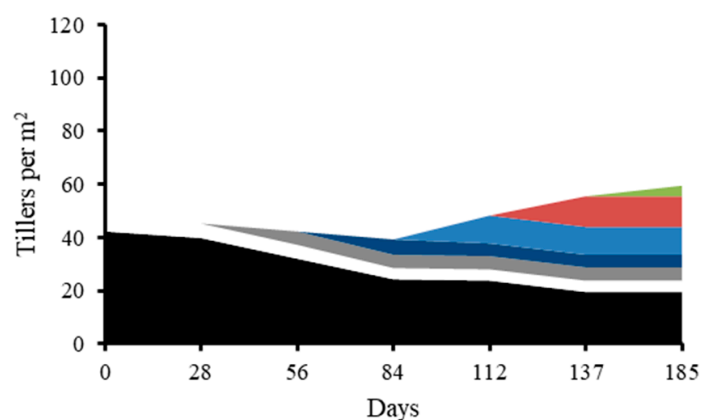

-GEN $12 \quad$ GEN $2 \quad=$ GEN $3 \quad$ GEN 4 -GEN $5 \quad$ " GEN 6 $=$ GEN 7

Figure 2. Population dynamics of tillers of Panicum cultivars in the Brazilian semiarid region.

Interaction between the cultivar and evaluation period $(\mathrm{P}=0.001)$ was observed for ApR: the cultivars Tamani and Tanzânia revealed higher ApR at 122 and 137 days after establishment. In the other evaluation periods, the cultivars behaved similarly (Table 2). 
Table 2. Tiller appearance rate of Panicum cultivars in the Brazilian semiarid region at different periods after establishment.

\begin{tabular}{ccccccc}
\hline Periods (Days) & Massai & Tanzânia & Aruana & Zuri & Mombaça & Tamani \\
\hline 28 & $0.90^{\mathrm{aA}}$ & $0.25^{\mathrm{aB}}$ & $0.48^{\mathrm{aA}}$ & $0.20^{\mathrm{aA}}$ & $0.31^{\mathrm{aA}}$ & $0.50^{\mathrm{aB}}$ \\
56 & $0.44^{\mathrm{aAB}}$ & $0.40^{\mathrm{aB}}$ & $0.26^{\mathrm{aA}}$ & $0.31^{\mathrm{aA}}$ & $0.01^{\mathrm{aA}}$ & $0.23^{\mathrm{aB}}$ \\
84 & $0.27^{\mathrm{aB}}$ & $0.15^{\mathrm{aB}}$ & $0.01^{\mathrm{aA}}$ & $0.24^{\mathrm{aA}}$ & $0.24^{\mathrm{aA}}$ & $0.23^{\mathrm{aB}}$ \\
122 & $0.43^{\mathrm{bAB}}$ & $1.16^{\mathrm{aA}}$ & $0.01^{\mathrm{bA}}$ & $0.44^{\mathrm{bA}}$ & $0.31^{\mathrm{bA}}$ & $1.30^{\mathrm{aA}}$ \\
137 & $0.39^{\mathrm{bAB}}$ & $0.90^{\mathrm{aA}}$ & $0.30^{\mathrm{bA}}$ & $0.42^{\mathrm{bA}}$ & $0.33^{\mathrm{bA}}$ & $1.20^{\mathrm{aA}}$ \\
185 & $0.68^{\mathrm{aAB}}$ & $0.10^{\mathrm{aB}}$ & $0.29^{\mathrm{aA}}$ & $0.23^{\mathrm{aA}}$ & $0.16^{\mathrm{aA}}$ & $0.02^{\mathrm{aB}}$
\end{tabular}

Means followed by distinct lowercase letters in the row and uppercase letters in the column differ $(P<0.05)$ according to the Tukey test.

No interaction between the cultivar and evaluation period was observed for the MorB $(\mathrm{P}=0.1952)$ and $\operatorname{SuvP}(P=0.4590)$ of tillers. In addition, the cultivar $(P=0.3800)$ and evaluation period $(P=0.4469)$ had no effect on SuvP, with a mean and standard error of $99.1 \pm 1.7 \%$. However, higher MorB was detected in the cultivars Aruana and Tamani, relative to Mombaça and Zuri, with intermediate values detected in the other cultivars (Figure 3). Regarding the MorB, according to the experimental period, the highest values were observed at 56 days, while the lowest values were observed at 185 days; no difference was observed for the other evaluation periods.
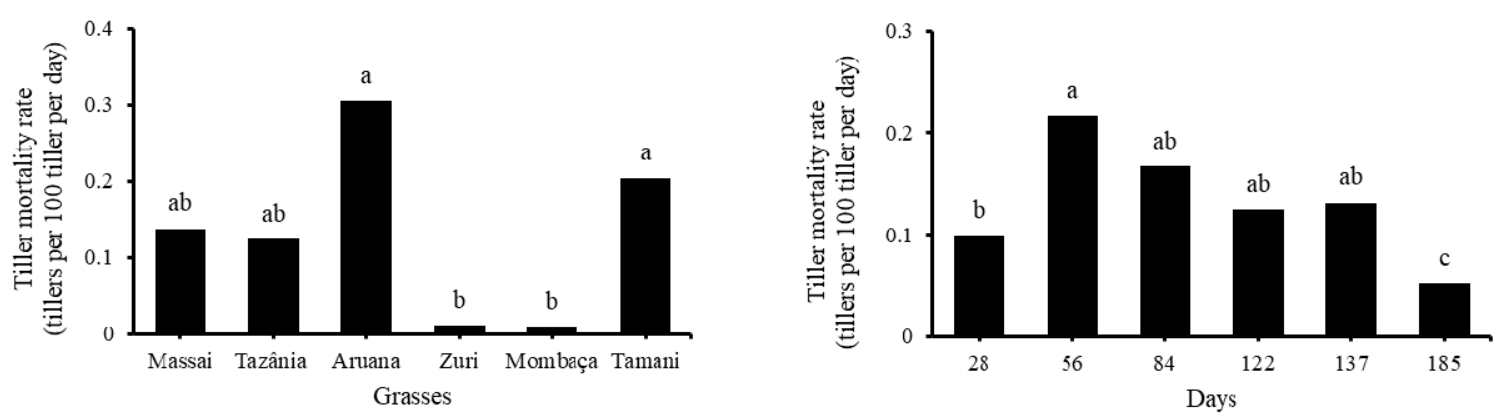

Figure 3. Mortality rate of tillers of Panicum cultivars during 185 days in the Brazilian semiarid region.

The stability index of the tiller population was greater than or equal to 1 for all cultivars throughout the experimental period, which indicates that the ApR was always higher than the MorB (Figure 4). Nevertheless, the cultivars Massai and Tamani obtained the smallest variations in the tiller population. 


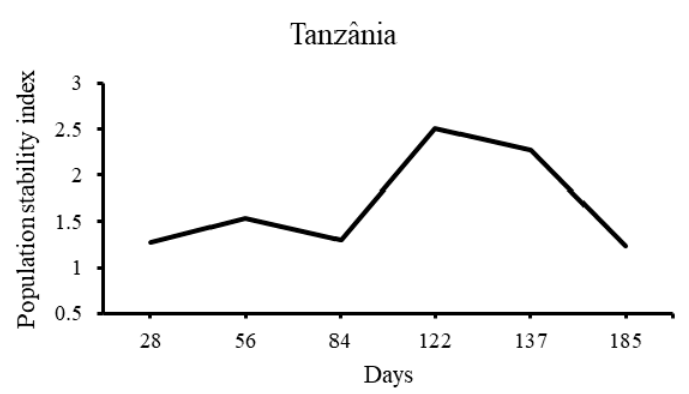

Aruana

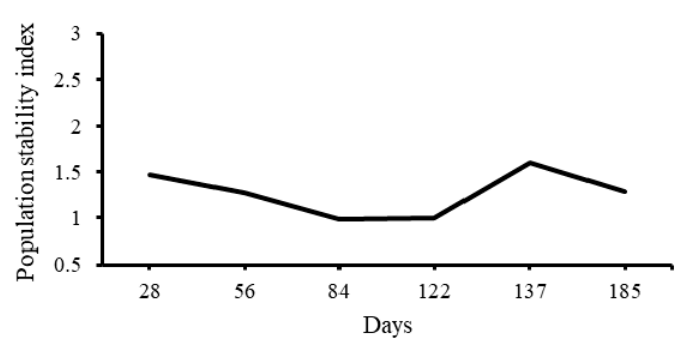

Mombaça

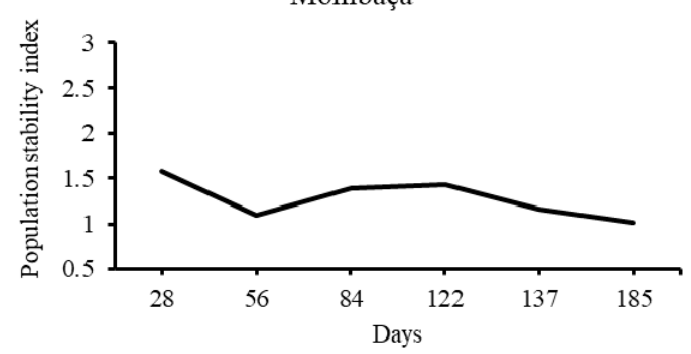

Massai

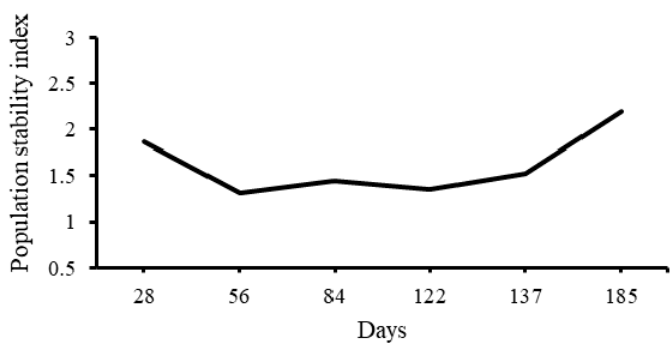

Zuri

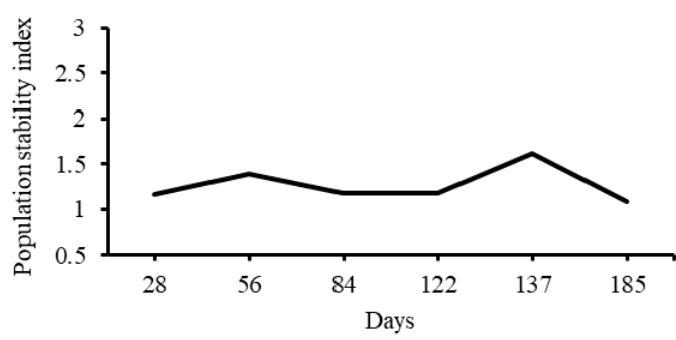

Tamani

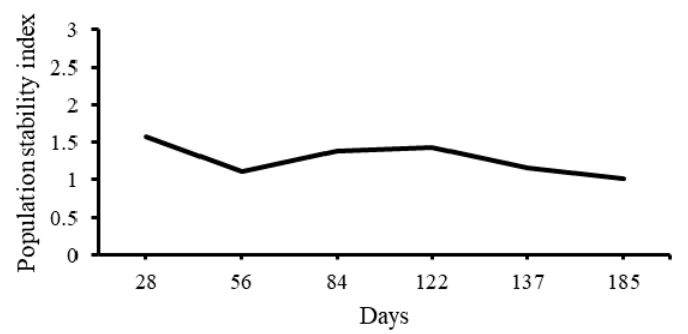

Figure 4. Stability index of the tiller population of Panicum cultivars in the Brazilian semiarid region.

\subsection{Structural Characteristics of Pastures}

The highest height by plant stems was observed in the cultivar Mombaça and the lowest in Aruana, with intermediate values for the other cultivars. Moreover, the highest LI by the canopy was detected in the cultivars Massai, Tamani, and Tanzânia and the lowest in Aruana and Zuri, with intermediate values in Mombaça (Table 3).

Tiller population density differed among cultivars: the highest TPD was observed in the cultivars Massai and Tamani and the lowest in Aruana, Mombaça, and Zuri, with no difference in Tânzania (Table 3).

The cultivars Massai, Mombaça, and Tamani had the highest FM; however, the largest mass of leaf blades was noted in Massai and Mombaça. The largest stem mass was found for the cultivars Mombaça and Zuri. No effect of cultivar occurred for the mass of dead material ( $P>0.05)$. The leaf blade/stem ratio was higher in the cultivars Massai, Tamani, and Tanzânia (Table 3). 
Table 3. Structural characteristics of different Panicum cultivars cultivated in the Brazilian semiarid region.

\begin{tabular}{|c|c|c|c|c|c|c|c|c|}
\hline \multirow{2}{*}{ Variables } & \multicolumn{6}{|c|}{ Cultivars } & \multirow{2}{*}{ EPM } & \multirow{2}{*}{ Valor $\mathbf{P}$} \\
\hline & Massai & Tanzânia & Aruana & Zuri & Mombaça & Tamani & & \\
\hline Height $(\mathrm{cm})$ & $50.9^{b}$ & $61.6^{\mathrm{ab}}$ & $34.9^{c}$ & $58.1^{\mathrm{ab}}$ & $74.1^{\mathrm{a}}$ & $43.3^{b}$ & 5.2 & 0.005 \\
\hline LI (\%) & $90.6^{\mathrm{a}}$ & $92.9^{\mathrm{a}}$ & $80.7^{b}$ & $77.2^{\mathrm{b}}$ & $87.4^{\mathrm{ab}}$ & $93.8^{\mathrm{a}}$ & 19.1 & 0.044 \\
\hline TPD (Perf/m²) & $427.8^{\mathrm{a}}$ & $294.0^{\mathrm{ab}}$ & $190.0^{\mathrm{b}}$ & $195.50^{\mathrm{b}}$ & $197.3^{b}$ & $323.50^{\mathrm{a}}$ & 18.8 & 0.001 \\
\hline $\mathrm{HM}\left(\mathrm{kg} \mathrm{ha}^{-1}\right.$ de MS) & $2979.0^{\mathrm{a}}$ & $2879.9^{a b}$ & $1648.6^{\mathrm{b}}$ & $2704.1^{a b}$ & $3249.0^{\mathrm{a}}$ & $2718.4^{\mathrm{a}}$ & 332.5 & 0.015 \\
\hline Leaf (kg ha ${ }^{-1}$ de MS) & $1781.5^{\mathrm{a}}$ & $1614.2^{\mathrm{ab}}$ & $784.9^{\mathrm{b}}$ & $1613.2^{\mathrm{ab}}$ & $1903.2^{\mathrm{a}}$ & $1855.6^{a b}$ & 40.7 & 0.016 \\
\hline Stem $\left(\mathrm{kg} \mathrm{ha}^{-1}\right.$ de MS) & $579.4^{\mathrm{ab}}$ & $529.3^{\mathrm{ab}}$ & $403.2^{\mathrm{b}}$ & $600.8^{\mathrm{a}}$ & $736.0^{a}$ & $536.0^{\mathrm{a}}$ & 20.0 & 0.001 \\
\hline Dead material (kg ha ${ }^{-1}$ de MS) & 618.0 & 636.4 & 460.4 & 490.15 & 609.9 & 657.8 & 20.7 & 0.089 \\
\hline $\mathrm{L} / \mathrm{S}$ & $3.1^{\mathrm{a}}$ & $3.0^{\mathrm{a}}$ & $1.9^{\mathrm{b}}$ & $2.7^{\mathrm{ab}}$ & $2.6^{\mathrm{ab}}$ & $3.4^{\mathrm{a}}$ & 2.8 & 0.001 \\
\hline
\end{tabular}

Means followed by different letters on the line differ $(\mathrm{P}<0.05)$ according to the Tukey test. EPM: standard error of the mean; LI: light interception; TPD: tiller population density; HM: herbage mass; L/S: leaf/stem ratio.

\section{Discussion}

\subsection{Tiller Population Dynamics}

The first generation of tillers corresponded to the number of tillers of various ages present on the first appointment date. As the date of appearance could not be identified, this generation was more numerous, regardless of the cultivar. This result may also have been enhanced by nitrogen fertilization applied after the uniform cut. The largest number of tillers observed in the Massai grass generations can be attributed to the cultivar's genetics $[9,15]$. The number of leaves and tillers formed in the cultivar Massai is greater than any other of the genus Panicum already known [15].

The third and fourth generations of tillers were smaller because the assessment coincided with the period of least precipitation, which resulted in the largest water deficit in the soil (Figure 1). In this condition, the plant's metabolism is slower and thus the processes involved in the emergence of new tillers [16]. The increase in tillering observed in the seventh generation, mainly in the cultivar Massai, is the result of the resumption of the rainy season, which was the only period when the soil had a positive water balance (Figure 1). The cultivar Massai has a rapid recovery after a period of water scarcity [10]. In the semiarid region, where the rainy season is short (May to August), the more responsive a cultivar is, the longer the pasture will be used in the production system.

As to the MorB, the cultivar Aruana presented the highest values together with Tamani. This response observed in the cultivar Aruana can probably be explained by its higher requirement for fertility and water relative to that of the other cultivars. Fernandes et al. [17], evaluating the structural characteristics of the different tropical grasses that sheep graze in the Brazilian semiarid region ( $5^{\circ} 53^{\prime} 34^{\prime \prime} \mathrm{S}$ and $\left.35^{\circ} 21^{\prime} 50^{\prime \prime} \mathrm{W}\right)$ during the dry season, demonstrated that the cultivar Aruana has less tolerance to water deficit, requiring the removal of animals in the second grazing cycle due to low forage supply. Regarding the cultivation of Tamani, despite having high MorB, it revealed higher ApR, which translates into greater tissue renewal, therefore generating generations with a shorter life span, providing a younger tiller population. At 185 days, the lowest MorB was recorded for all cultivars due to the resumption of the rainy season.

The tiller population stability index was higher than 1 for all cultivars, which indicates that survival and tillering were able to compensate for MorB; the tiller population thus tends to increase over the years. However, with the exception of the cultivar Massai, all other cultivars decreased the TPD over the experimental period, a response consistent with the time of assessment, since with the increase in water deficit in the soil, the rate of appearance tends to be lower than the MorB due to increased competition for water and light among tillers [7].

\subsection{Structural Characteristics of Pastures}

The highest canopy height was registered in the grasses of Mombaça grass, as it is the largest of the Panicum maximum cultivars $[9,18]$. The greater LI found for the cultivars Massai, Tamani, and Tanzânia 
can be explained by the higher TPD observed in these cultivars (Table 3). These were the cultivars that came closest to reaching the critical leaf area index, a condition in which the pasture intercepts $95 \%$ of the incident light $[2,19,20]$. Competition for light therefore did not occur at the base of the plant, which could inhibit tillering.

The cultivars Massai and Tamani demonstrated higher population densities of tillers compared to Aruana, Mombaça, and Zuri due to the compensatory mechanism of tiller size/population density [21], where taller plants have large tillers but in smaller quantities and vice versa. When assessing the tillering capacity of tropical grass cultivars, Luna et al. [9] reported a population of tillers $62 \%$ higher in the cultivar Massai compared to Mombaça. The advantage of cultivars that have a higher TPD is that tillers are essential for the persistence of pastures due to their enhanced efficiency in the use of resources such as water, nutrients, and light [22], which promotes a quick recovery after a period of scarcity of these factors [10].

The largest FM found in the cultivars Massai and Tamani is the result of the high TPD. In tropical pastures, morphogenic characteristics (leaf appearance and elongation rate, leaf life duration, and stem elongation rate) dictate the tillering dynamics and determine the structural responses, which explains the phenomenon described above [23].

The cultivar Mombaça, despite having a lower population density, is the larger cultivar that promoted a compensatory effect on the FM due to the relationship between the height of the pasture and FM [24,25]. Still, for the cultivar Massai, the largest leaf mass and smallest stem promoted a higher leaf/stem ratio for this cultivar. Conversely, the cultivar Mombaça presented greater leaf and stem masses. As it is a higher cultivar, the proportion of the stem and leaf of Mombaça was expected to differ from that of the other cultivars due to its greater stalk elongation and longer leaf blade [16].

\section{Conclusions}

The cultivars Massai, Mombaça, Tamani, Tanzânia, and Zuri have the potential to be cultivated in areas with marked water deficit and high temperatures, such as the Brazilian semiarid region. The cultivar Massai has a rapid recovery after a period of water scarcity. The cultivar Aruana is not recommended for use in the Brazilian semiarid region under rainfed conditions because it presented low stability, low tiller appearance rates, high tiller mortality rates that resulted in the lowest forage mass, which can compromise its persistence when submitted to grazing.

Author Contributions: Conceptualization: E.L.d.L.V., G.d.S.D. and J.V.E.N.; formal analysis: G.d.S.D. and A.L.C.G.; funding acquisition: G.d.S.D.; investigation: E.L.d.L.V., A.B.G.d.C., J.G.R., M.d.G.P. and P.R.C.; methodology: E.L.d.L.V., A.B.G.d.C. and J.G.R.; resources: G.d.S.D.; software: A.L.C.G.; supervision: E.L.d.L.V. and G.d.S.D.; validation: C.M.C. and J.V.E.N.; writing-original draft: G.d.S.D., A.L.C.G. and C.M.C.; writing-review and editing: G.d.S.D., A.L.C.G. and J.V.E.N. All authors have read and agreed to the published version of the manuscript.

Funding: This research was funded by the grant number: 001 [Coordination for the Improvement of Higher Education Personnel - Brazil (CAPES)]; National Council for Scientific and Technological Development (CNPq); Federal University of Rio Grande do Norte. Supported by the Federal University of Mato Grosso do Sul.

Conflicts of Interest: The authors declare no conflict of interest.

\section{References}

1. Braz, T.G.S.; Martuscello, J.A.; Jank, L.; Fonseca, D.M.; Resende, M.D.V.; Evaristo, A.B. Genotypic value in hybrid progenies of Panicum maximum Jacq. Cienc. Rural. 2017, 47, 1-6. [CrossRef]

2. Euclides, V.P.B.; Carpejani, G.C.; Montagner, D.B.; Nascimento Junior, D.; Barbosa, R.A.; Difante, G.S. Maintaining post-grazing sward height of Panicum maximum (cv. Mombaça) at $50 \mathrm{~cm}$ led to higher animal performance compared with post-grazing height of $30 \mathrm{~cm}$. Grass Forage Sci. 2018, 73, 174-182. [CrossRef]

3. Emerenciano Neto, J.V.; Difante, G.S.; Lana, Â.M.Q.; Medeiros, H.R.; Aguiar, E.M.; Montagner, D.B.; Souza, J.S. Forage quality and performance of sheep in Massai grass pastures managed at pre-grazing canopy heights. S. Afr. J. Anim. Sci. 2018, 48, 1073-1081. [CrossRef] 
4. Fahad, S.; Bajwa, A.A.; Nazir, U.; Anjum, S.A.; Farooq, A.; Zohaib, A.; Sadia, S.; Nasim, W.; Adkins, S.; Saud, S.; et al. Crop production under drought and heat stress: Plant responses and management options. Front. Plant. Sci. 2017, 8, 1147. [CrossRef] [PubMed]

5. Habermann, E.; Oliveira, E.A.D.; Contin, D.R.; Delvecchio, G.; Viciedo, D.O.; De Moraes, M.A.; Prado, R.M.; Costa, K.A.P.; Braga, M.R.; Martinez, C.A. Warming and water deficit impact leaf photosynthesis and decrease forage quality and digestibility of a C4 tropical grass. Physiol. Plant. 2019, 165, 383-402. [CrossRef]

6. Sousa, B.M.L.; Rizato, C.A.; Fagundes, J.L.; Fontes, P.T.N.; Backes, A.A.; Oliveira Junior, L.F.G.; Nascimento, C.S. Tillering dynamics of digit grass subject to different defoliation frequencies. Pesqui. Agropecu. Bras. 2019, 54, 1-9. [CrossRef]

7. Difante, G.S.; Nascimento Júnior, D.; Da Silva, S.C.; Euclides, V.P.B.; Zanine, A.M.; Adese, B. Dinâmica do perfilhamento do capim-marandu cultivado em duas alturas e três intervalos de corte. Rev. Bras. Zootec. 2008, 37, 189-196. [CrossRef]

8. Montagner, D.B.; Nascimento Júnior, D.; Vilela, H.H.; Sousa, B.M.L.; Euclides, V.P.B.; Da Silva, S.C.; Carloto, S.C. Tillering dynamics in pastures of guinea grass subjected to grazing severities under intermittent stocking. Rev. Bras. Zootec. 2012, 41, 544-549. [CrossRef]

9. Luna, A.A.; Difante, G.S.; Montagner, D.B.; Emerenciano Neto, J.V.; Araujo, I.M.M.; Fernandes, L.S. Tillering dynamic and structural characteristics oftropical grasses under cutting management. Biosci. J. 2016, 32, 1008-1017. [CrossRef]

10. Gurgel, A.L.C.; Difante, G.S.; Emerenciano Neto, J.V.; Souza, J.S.; Veras, E.L.L.; Costa, A.B.G.; Carvalho Netto, R.T.; Fernandes, L.S.; Cunha, J.C.; Roberto, F.F.S. Estrutura do pasto e desempenho de ovinos em capim-massai na época seca em resposta ao manejo do período das águas. Bol. Ind. Anim. 2017, 74, 86-95. [CrossRef]

11. Cândido, M.J.D.; Lopes, M.N.; Furtado, R.N.; Pompeu, R.C.F.F. Potencial e desafios para a produção animal sustentável em pastagens cultivadas do Nordeste. Rev. Cienc. Prod. Anim. 2018, 20, 59-70.

12. Thorthwaite, C.W. An approach toward a rational classification of climate. Geog. Ver. 1948, 38, 55-93. [CrossRef]

13. International Soil Classification System for Naming Soils and Creating Legends for Soil Maps; Update 2015; World Soil Resources Raport 106; FAO: Rome, Italy, 2015; 188p.

14. Bahmani, I.; Thom, E.R.; Matthew, C.; Hooper, R.J.; Lemaire, G. Tiller dynamics of perennial ryegrass cultivars derived from different New Zealand ecotypes: Effects of cultivar, season, nitrogen fertilizer, and irrigation. Aust. J. Agric. Res. 2003, 54, 803-817. [CrossRef]

15. Martuscello, J.A.; Silva, L.P.; Cunha, D.N.F.V.; Batista, A.C.S.; Braz, T.G.S.; Ferreira, S.P. Adubação nitrogenada em capim-massai: Morfogênese e produção. Ci. Anim. Bras. 2015, 16,1-13. [CrossRef]

16. Luna, A.A.; Difante, G.S.; Montagner, D.B.; Emerenciano Neto, J.V.; Araujo, I.M.M.; Oliveira, L.E.C. Características morfogênicas e acúmulo de forragem de gramíneas forrageiras sob corte. Biosci. J. 2014, 30, 1803-1810.

17. Fernandes, L.S.; Difante, G.S.; Costa, M.G.; Emerenciano Neto, J.V.; Araújo, I.M.M.; Dantas, J.L.S.; Gurgel, A.L.C. Pasture structure and sheep performance supplemented on different tropical grasses in the dry season. Revista Mexicana de Ciencias Pecuarias 2020, 11, 89-101. [CrossRef]

18. Silveira, M.C.T.; Nascimento Júnior, D.; Da Silva, S.C.; Euclides, V.P.B.; Montagner, D.B.; Sbrissia, A.F.; Rodrigues, C.S.; Sousa, B.M.L.; Karine Da Silva Pena, K.S.; Vilela, H.H. Morphogenetic and structural comparative characterization of tropical forage grass cultivars under free growth. Sci. Agric. 2010, 67, 136-142. [CrossRef]

19. Carnevalli, R.A.; Da Silva, S.C.; Bueno, A.A.O.; Uebele, M.C.; Bueno, F.O.; Hodgson, J.; Morais, J.P.G. Herbage production and grazing losses in Panicum maximum cv. mombaça under four grazing managements. Trop. Grassl. 2006, 40, 165-176.

20. Barbosa, R.A.; Nascimento Júnior, D.D.; Euclides, V.P.; Silva, S.C.; Zimmer, A.H.; Júnior, T.; de Almeida, R.A. Capim-tanzânia submetido a combinações entre intensidade e frequência de pastejo. Pesqui. Agropecu. Bras. 2007, 42, 329-340. [CrossRef]

21. Sbrissia, A.F.; Da Silva, S.C. Compensação tamanho: Densidade populacional de perfis em pastos de capim-marandu. Rev. Bras. Zootec. 2008, 37, 35-47. [CrossRef] 
22. Lopes, M.N.; Cândido, M.J.D.; Pompeu, P.C.F.F.; Silva, R.D.; Bezerra, F.M.L. Componentes estruturais do resíduo pós-corte em capim-massai adubado com cinco doses de nitrogênio. Rev. Ciênc. Agron. 2011, 42, 518-525. [CrossRef]

23. Difante, G.S.; Nascimento Júnior, D.; Da Silva, S.C.; Euclides, V.P.B.; Montagner, D.B.; Márcia Silveira, C.T.; Pena, K.S. Características morfogênicas e estruturais do capim-marandu submetido a combinações de alturas e intervalos de corte. Rev. Bras. Zootec. 2011, 40, 955-963. [CrossRef]

24. Santos, M.E.R.; Fonseca, D.M.; Oliveira, I.M.; Casagrande, D.R.; Balbino, E.M.; Freitas, F.P. Correlações entre número de perfilhos, índice de tombamento, massa dos componentes morfológicos e valor nutritivo da forragem em pastos diferidos de capim-braquiária. Rev. Bras. Zootecn. 2010, 39, 487-493. [CrossRef]

25. Oliveira, J.S.; Emerenciano Neto, J.V.; Difante, G.S.; Lista, F.N.; Santos, R.S.; Bezerra, J.D.V.; Bonfim, B.R.S.; Milhomens, L.B.S.; Ribeiro, J.S.M. Structural and productive features of Panicum cultivars submitted to different rest periods in the irrigated semiarid region of Brazil. Biosci. J. 2019, 35, 682-690. [CrossRef]

(C) 2020 by the authors. Licensee MDPI, Basel, Switzerland. This article is an open access article distributed under the terms and conditions of the Creative Commons Attribution (CC BY) license (http://creativecommons.org/licenses/by/4.0/). 